\title{
Modification of neuropathic pain sensation through microglial ATP receptors
}

\author{
Kazuhide Inoue • Makoto Tsuda • \\ Hidetoshi Tozaki-Saitoh
}

Received: 31 May 2007 / Accepted: 2 August 2007 / Published online: 25 August 2007

(C) Springer Science + Business Media B.V. 2007

\begin{abstract}
Neuropathic pain that typically develops when peripheral nerves are damaged through surgery, bone compression in cancer, diabetes, or infection is a major factor causing impaired quality of life in millions of people worldwide. Recently, there has been a rapidly growing body of evidence indicating that spinal glia play a critical role in the pathogenesis of neuropathic pain. Accumulating findings also indicate that nucleotides play an important role in neuron-glia communication through $\mathrm{P} 2$ purinoceptors. Damaged neurons release or leak nucleotides including ATP and UTP to stimulate microglia through P2 purinoceptors expressing on microglia. It was shown in an animal model of neuropathic pain that microglial $\mathrm{P} 2 \mathrm{X}_{4}$ and $\mathrm{P} 2 \mathrm{X}_{7}$ receptors are crucial in pain signaling after peripheral nerve lesion. In this review, we describe the modification of neuropathic pain sensation through microglial $\mathrm{P} 2 \mathrm{X}_{4}$ and $\mathrm{P} 2 \mathrm{X}_{7}$, with the possibility of $\mathrm{P} 2 \mathrm{Y}_{6}$ and $\mathrm{P} 2 \mathrm{Y}_{12}$ involvement.
\end{abstract}

Keywords Allodynia $\cdot$ ATP $\cdot$ Microglia $\cdot$ Neuropathic pain $\cdot$ $\mathrm{P} 2 \mathrm{X}_{4} \cdot$ Spinal cord

\begin{tabular}{|c|c|}
\hline \multicolumn{2}{|c|}{ Abbreviations } \\
\hline ADP & adenosine 5'-diphosphate \\
\hline ATP & adenosine 5 -triphosphate \\
\hline BDNF & brain-derived neurotrophic factor \\
\hline BzATP & $\begin{array}{l}2^{\prime}-\text { and } 3 '-O \text {-(4-benzoylbenzoyl) adenosine } \\
5^{\prime} \text {-triphosphate }\end{array}$ \\
\hline$\left[\mathrm{Ca}^{2+}\right]_{\mathrm{i}}$ & intracellular $\mathrm{Ca}^{2+}$ concentration \\
\hline
\end{tabular}

K. Inoue $(\bowtie) \cdot M$. Tsuda $\cdot$ H. Tozaki-Saitoh

Department of Molecular and System Pharmacology,

Graduate School of Pharmaceutical Sciences, Kyushu University,

3-1-1 Maidashi, Higashi,

Fukuoka 812-8582, Japan

e-mail: inoue@phar.kyushu-u.ac.jp

\begin{tabular}{|c|c|}
\hline CR3 & complement receptor 3 \\
\hline IL-1 $\beta$ & interleukin-1 $\beta$ \\
\hline IL-6 & interleukin-6 \\
\hline OATP & oxidized ATP \\
\hline PK11195 & $\begin{array}{l}\text { [1-(2-chlorophenyl)- } N \text {-methyl- } N \text {-(1-methyl- } \\
\text { propyl)-3-isoquinolineiso-quinoline } \\
\text { carboxamide] }\end{array}$ \\
\hline PPADS & $\begin{array}{l}\text { pyridoxalphosphate-6-azophenyl-2', } \\
\text { 4'-disulphonic acid }\end{array}$ \\
\hline TNP-ATP & $\begin{array}{l}\text { 2',3'-O-(2,4,6-trinitrophenyl)adenosine } \\
\text { 5'-triphosphate }\end{array}$ \\
\hline $\mathrm{TNF}-\alpha$ & tumor necrosis factor- $\alpha$ \\
\hline UDP & uridine 5'-diphosphate \\
\hline IL-1 $\beta$ & interleukin-1 $\beta$ \\
\hline
\end{tabular}

\section{Introduction}

There is a type of pain that does not go away even though the tissue has already healed. One type of this pain is called neuropathic pain that typically develops when peripheral nerves are damaged such as through surgery, bone compression in cancer, diabetes, or infection. Neuropathic pain is a major factor causing impaired quality of life in millions of people worldwide and is frequently resistant to all known analgesic drugs. Over the last decade, accumulating evidence concerning how peripheral nerve injury creates neuropathic pain has suggested that nerve injury produces molecular and cellular alterations that result in multiple forms of neuronal plasticity and anatomical reorganization in the dorsal horn of the spinal cord. These alterations have been proposed to be crucial in the pathogenesis of neuropathic pain $[1,2]$. While the dominant theme in research on neuropathic pain has been to 
understand the roles of neurons in the peripheral nervous system and the dorsal horn, there is a rapidly growing body of evidence indicating that spinal glial cells play a critical role in the pathogenesis of neuropathic pain.

Recently, growing evidence has indicated that neuronglia interaction is a key idea to understand functions of the central nervous system (CNS). Especially glia play important roles in pathophysiological situations of the CNS including psychiatric disorders, physical trauma, and infections [3]. Glia consist of three members: astrocytes, oligodendrocytes, and microglia. Accumulating findings also indicate that nucleotides play an important role in neuron-glia communication through $\mathrm{P} 2$ purinoceptors, even though ATP is recognized primarily to be a source of free energy and nucleotides are key molecules in cells. Microglia, which are thought to be residential macrophages in the CNS, express $\mathrm{P} 2$ purinoceptors, mainly $\mathrm{P} 2 \mathrm{X}_{4}$ and $\mathrm{P} 2 \mathrm{X}_{7}$ as well as $\mathrm{P}_{2} \mathrm{Y}_{2}, \mathrm{P}_{2} \mathrm{Y}_{6}$, and $\mathrm{P}_{2} \mathrm{Y}_{12}$ [4]. Damaged neurons release or leak nucleotides including ATP and UTP to stimulate microglia $[5,6]$. It is clear that these nucleotides trigger the release of various neurotoxic and neuroprotective cytokines and growth factors via different purine receptors $[4,7]$ or induce $\mathrm{P}_{2} \mathrm{Y}_{12}$-dependent chemotaxis in cultured cells $[8,9]$. It was shown in an animal model of neuropathic pain that microglial $\mathrm{P} 2 \mathrm{X}_{4}$ and $\mathrm{P} 2 \mathrm{X}_{7}$ receptors are crucial in pain signaling after peripheral nerve lesion [10-12]. Other purine receptors are upregulated in microglia in response to neuronal injury, as was recently demonstrated for $\mathrm{P}_{2} \mathrm{Y}_{6}$ [6]. The $\mathrm{P}_{2} \mathrm{Y}_{6}$ receptor triggers microglial phagocytosis [6]. In this paper, we review the modification of pain sensation through microglial $\mathrm{P}_{2} \mathrm{X}_{4}$ and $\mathrm{P} 2 \mathrm{X}_{7}$, and also point out the possibility of $\mathrm{P} 2 \mathrm{Y}_{6}$ and $\mathrm{P} 2 \mathrm{Y}_{12}$ involvement in pain signaling.

\section{$\mathrm{P}_{2} \mathrm{X}_{4}$ in neuropathic pain}

We found that the marked tactile allodynia that develops following nerve injury was reversed by acutely administering TNP-ATP intrathecally but was unaffected by administering PPADS [10]. From the pharmacological profiles of TNP-ATP (blocking $\mathrm{P}_{2} \mathrm{X}_{4}$ at high concentration) and PPADS (not blocking $\mathrm{P}_{2} \mathrm{X}_{4}$ ), it was suggested that tactile allodynia depends upon $\mathrm{P}_{2} \mathrm{X}_{4}$ in the spinal cord. The expression of $\mathrm{P}_{2} \mathrm{X}_{4}$ protein, normally low in the naïve spinal cord, progressively increased in the days following nerve injury with a time course parallel to that of the development of tactile allodynia. Double immunolabeling analysis demonstrated that not neurons or astrocytes but activated microglia in the dorsal horn were intensely positive for $\mathrm{P}_{2} \mathrm{X}_{4}$ protein [10]. Moreover, intrathecally administered antisense oligodeoxynucleotide for $\mathrm{P} 2 \mathrm{X}_{4} \mathrm{R}$ reduced the expression of $\mathrm{P}_{2} \mathrm{X}_{4}$ protein in spinal microglia and prevented the development of the nerve injury-induced tactile allodynia. In naïve rats, intrathecal administration of cultured microglia that were preincubated with ATP to activate $\mathrm{P}_{2} \mathrm{X}_{4}$ produced tactile allodynia over the $3-5 \mathrm{~h}$ after the administration [10].

Since it was already reported that the nerve injuryinduced tactile allodynia depends on a depolarizing shift in the $\mathrm{E}_{\text {anion }}$ of spinal lamina I (LI) neurons in the dorsal spinal cord, resulting in converting the $\mathrm{GABA}_{\mathrm{A}}$ receptorand glycine receptor-mediated inhibition to excitation [13], it was considered that microglia may affect $\mathrm{E}_{\text {anion }}$ in LI neurons. To investigate this possibility, microglia were administered to the lumbar spinal level of naïve rats by an intrathecal catheter as described [11]. Administering microglia stimulated with ATP caused a progressive tactile allodynia over the $5 \mathrm{~h}$ after injection. $\mathrm{E}_{\text {anion }}$ in LI neurons from rats administered ATP-stimulated microglia was shifted to $-61.6 \mathrm{mV}$ from $-68.3 \mathrm{mV}$ of normal rats. In addition, we found that GABA response switched from hyperpolarizing in control rats to depolarizing in microgliatreated rats. Activated microglia secrete various biologically active molecules, one of which, BDNF, was implicated in the hypersensitivity of dorsal horn neurons that follows sensitization and inflammation [14-16] and in anion gradient shifts in the hippocampus [17]. Indeed, intrathecal administration of recombinant BDNF produced tactile allodynia comparable to that produced by ATP-stimulated microglia [11]. $E_{\text {anion }}$ of LI neurons in slices treated with BDNF ( $>90 \mathrm{~min}$, in vitro) was significantly less negative than that of $\mathrm{LI}$ neurons from control slices. The rise in $\left[\mathrm{Ca}^{2+}\right]_{\mathrm{i}}$ was prevented by the $\mathrm{GABA}_{\mathrm{A}}$ receptor blocker bicuculline, confirming that the effect was mediated by $\mathrm{GABA}_{\mathrm{A}}$ receptors. Thus, acute administration of BDNF in slices caused a depolarizing shift in $\mathrm{E}_{\text {anion }}$ and caused GABA to produce net excitation [11]. Moreover, a function-blocking antibody against the TrkB receptor (anti-TrkB) and a BDNFsequestering fusion protein (TrkB-Fc) acutely inhibited the allodynia and the shift of $E_{\text {anion }}$ of LI neurons [11]. The administration of ATP-stimulated microglia with either antiTrkB or TrkB-Fc did not develop tactile allodynia. After pretreatment of microglia with double-stranded short interfering RNA directed against BDNF (BDNF siRNA), the ATPstimulated microglia injected intrathecally into normal rats did not cause the allodynia [11]. Anti-TrkB and BDNF siRNA prevented the shift in $\mathrm{E}_{\text {anion }}$ induced by ATPstimulated microglia. ATP stimulation caused release of BDNF from microglia in culture. This effect of ATP was blocked by treating the cultures with the $\mathrm{P} 2 \mathrm{X}$ receptor blocker TNP-ATP. In addition, pretreatment of the microglia with BDNF siRNA prevented release of BDNF by ATP stimulation. By bath application of TNP-ATP to spinal slices taken from allodynic rats 2 weeks after nerve injury, $\mathrm{E}_{\text {anion }}$ of LI neurons was returned to normal value [11]. These findings 
indicate that $\mathrm{P}_{2} \mathrm{X}_{4}$-dependent release of BDNF from microglia is necessary to sustain both the tactile allodynia and the depolarizing shift in $\mathrm{E}_{\text {anion }}$ in LI neurons that result from nerve injury (Fig. 1).

\section{$\mathbf{P} 2 \mathrm{X}_{7}$ in neuropathic pain}

$\mathrm{P} 2 \mathrm{X}_{7}$ purinoceptors are a ligand-gated nonselective cationic channel and are expressed predominantly on immune cells [18]. Stimulation of the $\mathrm{P} 2 \mathrm{X}_{7}$ receptors on microglia is associated with release of cytokines including tumor necrosis factor- $\alpha$ (TNF- $\alpha)$ [5, 19], interleukin-6 (IL-6) [20], and interleukin-1 $\beta$ (IL-1 $\beta$ ) [21-23]. Several cytokines such as IL- $1 \beta$, IL-6, and TNF- $\alpha$ in the dorsal horn are increased after nerve lesion [24-26] and have been implicated in contributing to neuropathic pain [24-27]. Recent evidence indicates the relationship between TNF- $\alpha$ and neuropathic pain [28-32], and TNF- $\alpha$ released after injury is proposed as an initiator of abnormal pain sensation. TNF- $\alpha$ is upregulated after nerve injury in both dorsal root ganglion (DRG) and spinal cord [33]. The inhibition of TNF- $\alpha$ reduces the hyperalgesia in neuropathic pain models [34]. Recent evidence indicates the relationship between inflammatory cytokines including IL-1 $\beta$ and neuropathic pain $[25,26,28]$. The expression of IL- $1 \beta$ is upregulated in the spinal cord of several rat neuropathy models [24-26]. These findings further support a role for central IL-1 $\beta$ in the development and maintenance of neuropathic pain through induction of a proinflammatory cytokine cascade (Fig. 1).

Recently, it was reported that in mice lacking $\mathrm{P}_{2} \mathrm{X}_{7}$ inflammatory and neuropathic hypersensitivity is completely absent to both mechanical and thermal stimuli, whilst normal nociceptive processing is preserved [12]. Contribution of $\mathrm{P}_{2} \mathrm{X}_{7}$ receptor to neuropathic pain is also demon-

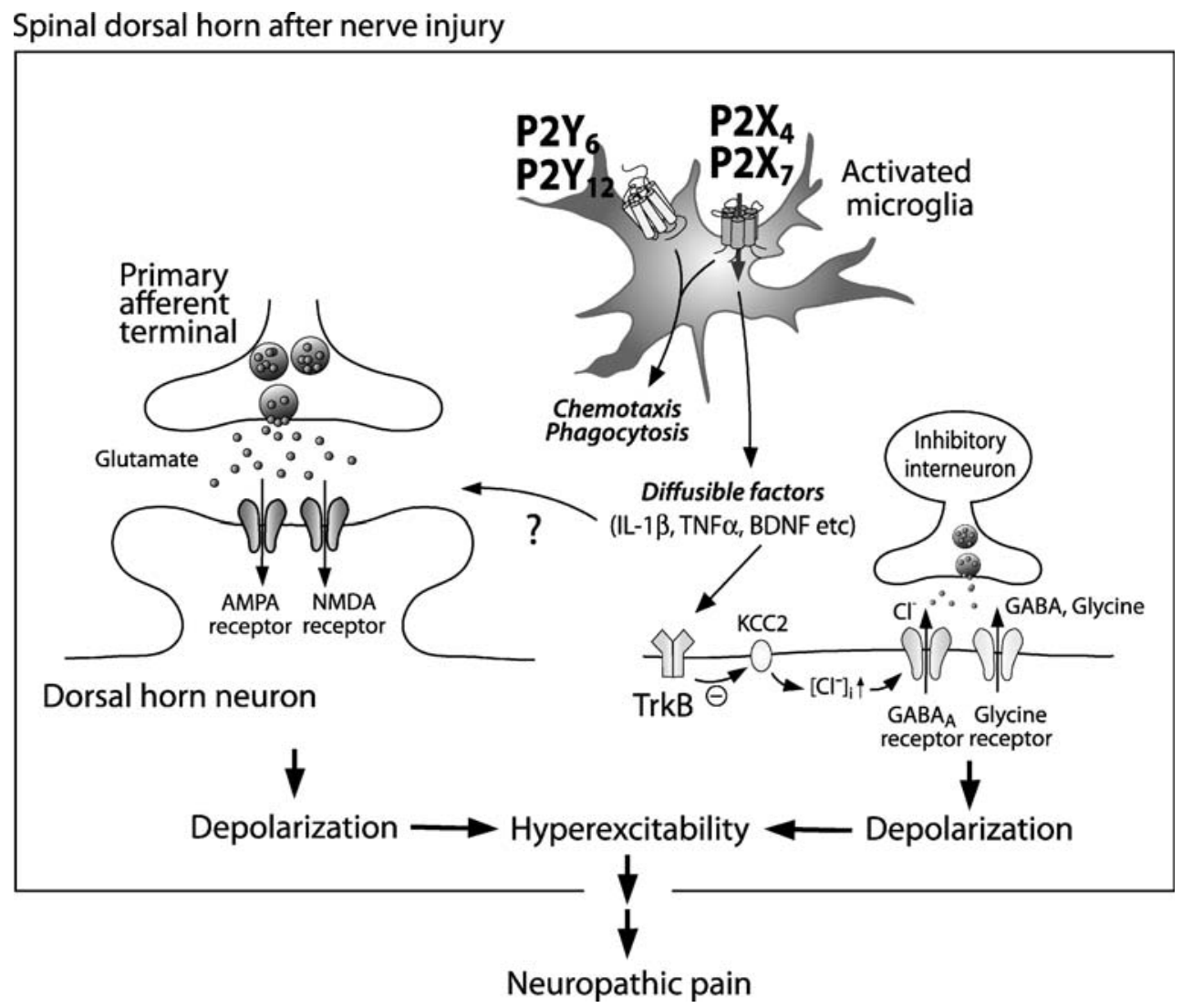

Fig. 1 Schematic illustration of potential mechanisms by which P2X/ $\mathrm{Y}$ receptors in activated microglia modulate neuropathic pain signaling in the dorsal horn. Activated microglia in the spinal cord after nerve injury express ionotropic ATP receptors [e.g., $\mathrm{P} 2 \mathrm{X}_{4}$ receptor $\left(\mathrm{P} 2 \mathrm{X}_{4} \mathrm{R}\right)$ or $\left.\mathrm{P} 2 \mathrm{X}_{7} \mathrm{R}\right]$. $\mathrm{P} 2 \mathrm{X}_{4} \mathrm{R}$ or $\mathrm{P} 2 \mathrm{X}_{7} \mathrm{R}$ activation leads to the release of bioactive diffusible factors such as BDNF and other proinflammatory factors (cytokines and chemokines). BDNF causes a collapse of transmembrane anion gradient in dorsal horn lamina I neurons presumably through the downregulation of $\mathrm{KCC} 2$, which in turn renders GABA and glycine effects depolarizing, rather than hyper-

polarizing, in these neurons. Microglial factors may also interact with excitatory synapses of neighboring dorsal horn neurons and enhance the excitability in dorsal horn neurons. The net hyperexcitability in the dorsal horn pain network by these factors from activated microglia may be responsible for neuropathic pain. Microglia also express $G$ protein-coupled ATP receptors [e.g., $\mathrm{P}_{2} \mathrm{Y}_{6}$ receptor $\left(\mathrm{P} 2 \mathrm{Y}_{6} \mathrm{R}\right)$ and $\left.\mathrm{P} 2 \mathrm{Y}_{12} \mathrm{R}\right]$. Activating $\mathrm{P} 2 \mathrm{Y}_{12} \mathrm{R}$ and $\mathrm{P} 2 \mathrm{Y}_{6} \mathrm{R}$ leads to chemotaxis and phagocytosis, respectively, but their functional relevance to neuropathic pain remained to be determined 
strated by using the recently developed selective antagonist for $\mathrm{P}_{2} \mathrm{X}_{7}$ receptor A-740003 [35]. The knockout animals were unimpaired in their ability to produce mRNA for pro$\mathrm{IL}-1 \beta$, and cytometric analysis of paw and systemic cytokines from knockout and wild-type animals following adjuvant insult suggested a selective effect of the gene deletion on release of IL-1 $\beta$ and IL-10, with systemic reductions in adjuvant-induced increases in IL-6 and MCP-1. In addition, $\mathrm{P} 2 \mathrm{X}_{7}$ receptors were upregulated in human dorsal root ganglia and injured nerves obtained from chronic neuropathic pain patients [12]. It was hypothesized that the $\mathrm{P} 2 \mathrm{X}_{7}$ receptor plays a common upstream transductional role in the development of pain of neuropathic and inflammatory origin via regulation of mature IL- $1 \beta$ production.

In addition, a recent study has shown that activation of $\mathrm{P}_{2} \mathrm{X}_{7}$ receptors expressed on satellite glia that enwrap each DRG neuron leads to a release of TNF- $\alpha$, which in turn increases the excitability of DRG neurons [36]. P2 $\mathrm{X}_{7}$ receptors are upregulated in surrounding satellite glial cells in the DRG in humans [12]. Implication of TNF- $\alpha$ has been reported in neuropathic pain [28-32]. Therefore, the contribution of $\mathrm{P} 2 \mathrm{X}_{7}$ receptor to neuropathic pain might be related not only to the activation of microglial $\mathrm{P} 2 \mathrm{X}_{7}$ receptors, but also to $\mathrm{P} 2 \mathrm{X}_{7}$ receptors on other cell types such as satellite glia.

\section{$\mathrm{P} \mathrm{Y}_{6}$ and $\mathrm{P} 2 \mathrm{Y}_{12}$ in neuropathic pain?}

When neurons are injured or dead, microglia are activated, resulting in their interaction with immune cells, active migration to the site of injury, release of proinflammatory substances, and the phagocytosis of damaged cells or debris. For such activation of microglial motilities, extracellular nucleotides have a central role. Extracellular ATP functions as a chemoattractant. Microglial chemotaxis by ATP via $\mathrm{P}_{2} \mathrm{Y}_{12}$ receptors was originally found by Honda et al. [8] and has recently been confirmed in vivo in $\mathrm{P}_{2} \mathrm{Y}_{12}$ receptor knockout animals [37]. Neuronal injury results in the release or leakage of ATP that appears to be a "find-me" signal from damaged neurons to microglia to cause chemotaxis. In addition to microglial migration by ATP, another nucleotide, UDP, an endogenous agonist of the $\mathrm{P}^{2} \mathrm{Y}_{6}$ receptor, greatly activates the motility of microglia and orders microglia to eat damaged neurons. UDP does not cause chemotaxis, but instead causes phagocytosis by microglia [6]. Phagocytosis, a specialized form of endocytosis, is the uptake by the cell of relatively large particles $(>1.0 \mu \mathrm{m})$ into vacuoles and has a central role in tissue remodeling, inflammation, and the defense against infectious agents [38]. Phagocytosis is initiated by the activation of various cell surface phagocytosis receptors, including $\mathrm{Fc}$ receptors, complement receptors, integrins, endotoxin receptors (CD18, CD14), mannose receptors, and scavenger receptors [39], which are activated by corresponding extracellular ligands. In the CNS, a full innate immune system, i.e., Fc receptors, complement system, scavenger receptors, and Toll-like receptors etc., has been described, and microglia reveal related roles as dedicated phagocytes. Since recognition is the first and the most important step for phagocytosis, extensive studies on phagocytosis receptors have been reported. It is well-known that dying cells express so-called eat-me signals such as phosphatidylserine on their surface membrane [39], by which microglia recognize the apoptotic cells to catch and remove them [39]. We first found that exogenously applied UDP caused microglial phagocytosis in a concentration-dependent manner, which was $\mathrm{P}_{2} \mathrm{Y}_{6}$ receptor-dependent. We found that neuronal injury caused by kainic acid (KA) upregulated $\mathrm{P}_{2} \mathrm{Y}_{6}$ receptors in microglia, the KA-evoked neuronal injury resulted in an increase in extracellular UTP, which was immediately metabolized into UDP in vivo and in vitro. Moreover, UDP leaked from injured neurons caused $\mathrm{P}_{2} \mathrm{Y}_{6}$ receptor-dependent phagocytosis in vivo and in vitro. These results suggest that UDP could be a molecule that signals the crisis of damaged neurons to microglia, triggering phagocytosis. It should be noted that nucleotides could be both "find-me" and "eat-me" signals. Cells release ATP, and we also found that KA caused an increase in extracellular UTP/UDP. Therefore microglia might be attracted by ATP/ADP [8, 40, 41] and subsequently recognize UDP, leading to the removal of the dying cells and their debris.

Are $\mathrm{P}_{2} \mathrm{Y}_{6}$ and $\mathrm{P} 2 \mathrm{Y}_{12}$ receptors involved in neuropathic pain? For this question, there is a report indicating that the UDP-sensitive $\mathrm{P}_{2} \mathrm{Y}_{6}$ receptor produces inhibitory effects on spinal pain transmission in a neuropathic pain model [42]. In the neuropathic pain model, in which the sciatic nerves of rats were partially ligated, UDP (30 and $100 \mathrm{nmol} / \mathrm{rat}$ ) produced significant antiallodynic effects. UDP $(100 \mathrm{nmol} / \mathrm{rat})$ caused no motor deficit in the inclined plane test [42]. The mechanism of this UDP-evoked inhibitory effect on neuropathic pain is unknown. There is no evidence to show the site (neuron or glia) of action of UDP. We are now investigating the involvement of $\mathrm{P} 2 \mathrm{Y}_{12}$ in pain signaling and have obtained evidence suggesting the role of $\mathrm{P} 2 \mathrm{Y}_{12}$ in the neuropathic pain state.

\section{Conclusion}

Neuropathic pain is a major factor causing impaired quality of life in millions of people worldwide. We have to try to reveal the mechanism of this pain in order to develop effective drugs against the pain. Recently, there has been a 
rapidly growing body of evidence indicating that spinal glia, especially microglia, play a critical role in the pathogenesis of neuropathic pain and that nucleotides play an important role in neuron-glia communication through P2 purinoceptors. We described the modification of neuropathic pain signaling through microglial $\mathrm{P} 2 \mathrm{X}_{4}$ and $\mathrm{P} 2 \mathrm{X}_{7}$, with the possibility of $\mathrm{P}_{2} \mathrm{Y}_{6}$ and $\mathrm{P} 2 \mathrm{Y}_{12}$ involvement (Fig. 1). It was shown in an animal model of neuropathic pain that microglial $\mathrm{P} 2 \mathrm{X}_{4}$ and $\mathrm{P} 2 \mathrm{X}_{7}$ receptors are crucial in pain signaling after peripheral nerve lesion. Microglial $\mathrm{P}_{2} \mathrm{Y}_{6}$ and $\mathrm{P} 2 \mathrm{Y}_{12}$ play very interesting roles for phagocytosis and chemotaxis, respectively. Besides, there is a possibility that these receptors are involved in pain sensation. Additional experiments are needed to clarify the possibility.

\section{References}

1. Woolf CJ, Mannion RJ (1999) Neuropathic pain: aetiology, symptoms, mechanisms, and management. Lancet 353:1959-1964

2. Scholz J, Woolf CJ (2002) Can we conquer pain? Nat Neurosci 5 Suppl:1062-1067

3. Miller G (2005) Neuroscience. The dark side of glia. Science 308:778-781

4. Inoue K (2006) The function of microglia through purinergic receptors: neuropathic pain and cytokine release. Pharmacol Ther 109:210-226

5. Wang X, Arcuino G, Takano $T$ et al (2004) P2X7 receptor inhibition improves recovery after spinal cord injury. Nat Med $10: 821-827$

6. Koizumi S, Shigemoto-Mogami Y, Nasu-Tada K et al (2007) UDP acting at $\mathrm{P} 2 \mathrm{Y} 6$ receptors is a mediator of microglial phagocytosis. Nature 446:1091-1095

7. Suzuki T, Hide I, Ido K et al (2004) Production and release of neuroprotective tumor necrosis factor by $\mathrm{P} 2 \mathrm{X} 7$ receptor-activated microglia. J Neurosci 24:1-7

8. Honda S, Sasaki Y, Ohsawa K et al (2001) Extracellular ATP or ADP induce chemotaxis of cultured microglia through Gi/ocoupled P2Y receptors. J Neurosci 21:1975-1982

9. Ohsawa K, Irino Y, Nakamura Y et al (2007) Involvement of P2X (4) and P2Y(12) receptors in ATP-induced microglial chemotaxis. Glia 55:604-616

10. Tsuda M, Shigemoto-Mogami Y, Koizumi S et al (2003) P2X4 receptors induced in spinal microglia gate tactile allodynia after nerve injury. Nature 424:778-783

11. Coull JA, Beggs S, Boudreau D et al (2005) BDNF from microglia causes the shift in neuronal anion gradient underlying neuropathic pain. Nature 438:1017-1021

12. Chessell IP, Hatcher JP, Bountra C et al (2005) Disruption of the P2X7 purinoceptor gene abolishes chronic inflammatory and neuropathic pain. Pain 114:386-396

13. Coull JA, Boudreau D, Bachand K et al (2003) Trans-synaptic shift in anion gradient in spinal lamina I neurons as a mechanism of neuropathic pain. Nature 424:938-942

14. Mannion RJ, Costigan M, Decosterd I et al (1999) Neurotrophins: peripherally and centrally acting modulators of tactile stimulusinduced inflammatory pain hypersensitivity. Proc Natl Acad Sci U S A 96:9385-9390

15. Heppenstall PA, Lewin GR (2001) BDNF but not NT-4 is required for normal flexion reflex plasticity and function. Proc Natl Acad Sci U S A 98:8107-8112
16. Thompson SW, Bennett DL, Kerr BJ et al (1999) Brain-derived neurotrophic factor is an endogenous modulator of nociceptive responses in the spinal cord. Proc Natl Acad Sci U S A 96:77147718

17. Rivera C, Li H, Thomas-Crusells J et al (2002) BDNF-induced TrkB activation down-regulates the $\mathrm{K}+-\mathrm{Cl}-$ cotransporter $\mathrm{KCC} 2$ and impairs neuronal Cl- extrusion. J Cell Biol 159:747-752

18. Collo G, Neidhart S, Kawashima E et al (1997) Tissue distribution of the P2X7 receptor. Neuropharmacology 36:1277-1283

19. Hide I, Tanaka M, Inoue A et al (2000) Extracellular ATP triggers tumor necrosis factor-alpha release from rat microglia. J Neurochem 75:965-972

20. Shigemoto-Mogami Y, Koizumi S, Tsuda M et al (2001) Mechanisms underlying extracellular ATP-evoked interleukin-6 release in mouse microglial cell line, MG-5. J Neurochem 78:1339-1349

21. Ferrari D, Villalba M, Chiozzi P et al (1996) Mouse microglial cells express a plasma membrane pore gated by extracellular ATP. J Immunol 156:1531-1539

22. Ferrari D, Wesselborg S, Bauer MK et al (1997) Extracellular ATP activates transcription factor NF-kappaB through the P2Z purinoreceptor by selectively targeting NF-kappaB p65. J Cell Biol 139:1635-1643

23. Sanz JM, Di Virgilio F (2000) Kinetics and mechanism of ATPdependent IL-1 beta release from microglial cells. J Immunol 164:4893-4898

24. Sweitzer S, Martin D, DeLeo JA (2001) Intrathecal interleukin-1 receptor antagonist in combination with soluble tumor necrosis factor receptor exhibits an anti-allodynic action in a rat model of neuropathic pain. Neuroscience 103:529-539

25. Winkelstein BA, Rutkowski MD, Sweitzer SM et al (2001) Nerve injury proximal or distal to the DRG induces similar spinal glial activation and selective cytokine expression but differential behavioral responses to pharmacologic treatment. J Comp Neurol 439:127-139

26. Raghavendra V, Tanga F, DeLeo JA (2003) Inhibition of microglial activation attenuates the development but not existing hypersensitivity in a rat model of neuropathy. J Pharmacol Exp Ther 306:624-630

27. Watkins LR, Milligan ED, Maier SF (2001) Glial activation: a driving force for pathological pain. Trends Neurosci 24:450455

28. Wagner R, Myers RR (1996) Endoneurial injection of TNFalpha produces neuropathic pain behaviors. Neuroreport 7:2897-2901

29. Sommer C, Schafers M (1998) Painful mononeuropathy in C57BL/Wld mice with delayed wallerian degeneration: differential effects of cytokine production and nerve regeneration on thermal and mechanical hypersensitivity. Brain Res 784:154162

30. Sommer C, Marziniak M, Myers RR (1998) The effect of thalidomide treatment on vascular pathology and hyperalgesia caused by chronic constriction injury of rat nerve. Pain 74:83-91

31. Sorkin LS, Doom CM (2000) Epineurial application of TNF elicits an acute mechanical hyperalgesia in the awake rat. $\mathrm{J}$ Peripher Nerv Syst 5:96-100

32. Schafers M, Geis C, Brors D et al (2002) Anterograde transport of tumor necrosis factor-alpha in the intact and injured rat sciatic nerve. J Neurosci 22:536-545

33. Hashizume H, DeLeo JA, Colburn RW et al (2000) Spinal glial activation and cytokine expression after lumbar root injury in the rat. Spine 25:1206-1217

34. Sommer C, Lindenlaub T, Teuteberg P et al (2001) Anti-TNFneutralizing antibodies reduce pain-related behavior in two different mouse models of painful mononeuropathy. Brain Res 913:86-89 
35. Honore P, Donnelly-Roberts D, Namovic MT et al (2006) A-740003 [N-(1-\{[(cyanoimino)(5-quinolinylamino) methyl] amino $\}$-2,2-dimethylpropyl)-2-(3,4-dimethoxyphenyl)acetamide], a novel and selective $\mathrm{P} 2 \mathrm{X} 7$ receptor antagonist, dose-dependently reduces neuropathic pain in the rat. J Pharmacol Exp Ther 319:1376-1385

36. Zhang X, Chen Y, Wang C et al (2007) Neuronal somatic ATP release triggers neuron-satellite glial cell communication in dorsal root ganglia. Proc Natl Acad Sci U S A 104:9864-9869

37. Haynes SE, Hollopeter G, Yang G et al (2006) The P2Y(12) receptor regulates microglial activation by extracellular nucleotides. Nat Neurosci 9:1512-1519

38. Tjelle TE, Lovdal T, Berg T (2000) Phagosome dynamics and function. Bioessays 22:255-263
39. Lauber K, Bohn E, Krober SM et al (2003) Apoptotic cells induce migration of phagocytes via caspase-3-mediated release of a lipid attraction signal. Cell 113:717-730

40. Davalos D, Grutzendler J, Yang G et al (2005) ATP mediates rapid microglial response to local brain injury in vivo. Nat Neurosci 8:752-758

41. Nimmerjahn A, Kirchhoff F, Helmchen F (2005) Resting microglial cells are highly dynamic surveillants of brain parenchyma in vivo. Science 308:1314-1318

42. Okada M, Nakagawa T, Minami M et al (2002) Analgesic effects of intrathecal administration of $\mathrm{P} 2 \mathrm{Y}$ nucleotide receptor agonists UTP and UDP in normal and neuropathic pain model rats. J Pharmacol Exp Ther 303:66-73 